\title{
the significance of the course events take in segmentary systems
}

\author{
PAUL DRESCH—University of Michigan
}

Segmentary lineage theory (or "lineage theory" for short) has had its day in studies of Middle Eastern tribalism. Nothing has satisfactorily replaced it. In the present paper I wish to suggest that although lineage theory is best discarded, the simpler idea of segmentation which underlay it is less easily dispensed with and remains useful. Lineage theory and segmentation are not at all the same thing; indeed, they represent two different types of anthropology. The first deals with sequences of events at the level of observation (and in particular with the appearance of groups), while the second deals with formal relations that characterize the types of events possible.

The distinction between the two is seldom made clearly, and the view of many anthropologists is well summarized by Eickelman as follows:

As an ideology of social relations among many tribal groups in the Middle East, the notion of segmentation has considerable importance. As a sociological model it is inadequate [Eickelman 1981:104|.

The approach being downgraded or limited here is that criticized by Peters (1967), and to define it negatively in this way is really necessary. For all the discussion of it, lineage theory is seldom definitively set out and must usually be reconstructed from the attacks of its critics. The one clear formulation of what it means to an adherent is Gellner's (1969:41-44), a very late recension of what he takes Evans-Pritchard to have said 30 years earlier (Evans-Pritchard 1974 [19401). Nonetheless, adherents and critics agree on the major points. The broad idea is, or was, that solidary groups form, and then combine or conflict, in predictable ways within a system sustained by a balance of power between its elements.' Peters (1967:270-272) showed that this did not occur among Cyrenaican pastoralists. The demonstration could be repeated for other tribal societies. That something like it was supposed to occur might form part of an "ideology" (Eickelman 1981:104).

The original idea of segmentation (Evans-Pritchard 1974 [1940]) seems quite different from this. It does not deal in terms of solidary groups or of a balance of power; ${ }^{2}$ indeed, such analysis of "social masses and a supposed relation between those masses" was explicitly rejected in the hope of establishing "relations between relations" (Evans-Pritchard 1974 [1940]:266). As a number of authors have noted, not least of them Dumont (1970:41), this has a much more modern ring. For all the worry about segmentation in Middle Eastern contexts it might never have been written. The argument is still usually, and perversely, about "social masses"-about "lineage theory" and not about segmentation at all."

Arguments about segmentation in the Middle Eastern context still turn on the presence or absence of solidary groups. Yemeni material is used to show that this is largely irrelevant. Segmentation concerns structural principles that apply to groups and individuals alike, to events that "follow the rules" and to those that contradict them. The principles of segmentation underlie a far wider range of events than those dealt with by segmentary lineage theory. IMiddle East, Yemen, segmentation, social structure, forms of action] 
One of the many results of this confusion is notorious: two well-known views of Morocco, each of which seems "formed on a different planet" from the other (Gilsenan 1982:280). Gellner (1969) accepts lineage theory, others (for example, Eickelman 1976; Rosen 1979) reject it, and neither side finds any sense to segmentation other than that which lineage theory gave it. Eickelman (1984:282-283), for instance, sees Evans-Pritchard and Gellner as simply engaged in a single enterprise (as, of course, does Gellner himself). By contrast, I am inclined to treat them as being poles apart. Indeed, when Eickelman (1984:285-286) writes of an "interpretive anthropology" that "takes as its point of departure an attempt to delineate the implicit assumptions which people themselves make concerning the nature of the social order," I would argue that this is very much what Evans-Pritchard was attempting in the first place. Gellner was not. The reaction to Gellner obscures a connection between aspects of Evans-Pritchard's work and the interpretivists' stated aims, a connection that needs to be recognized if the interpretive position is not to appear as extreme as Gellner's own.

The reaction, of course, has its own logic. If solidary groups are not to be found, then what one can find instead are "dyadic relations" and the "free-play of personality" (see, for example, Rosen $1979: 20,35,39,40$ ). Social structure is then to be based on these in a manner oddly reminiscent of an earlier transactionalist rejection of structural functionalism, and an alternative (though well-established) view of structure is passed by. ${ }^{4}$ Ties between individuals replace ties between groups, but they are still ties of much the same type, just as little abstracted from particular cases: the "social masses" are simply whittled down to persons or actors.

The problems that have been very ably brought to light in Moroccan ethnography are of general relevance. They apply just as much to Yemeni material, for example, and it is the Yemeni case I shall use to show what I think segmentation amounts to. It should be made clear that I am limiting myself to Middle Eastern material. The issue of segmentation has developed differently in other areas-for example, New Guinea has benefited from several classic analyses (for example, Barnes 1962; Meggitt 1965), and for a recent collection of impressive ethnographic breadth the reader can safely be referred to Holy (1979)—but in the Middle Eastern context the debate on segmentation has taken a distinctive turn. Elsewhere (Dresch 1984a) I have taken issue with Gellner's view of the matter. Here I discuss only that of an interpretive position in which "persons are conceived as the fundamental units of social structure" (Eickelman 1984:286). Several other readings deserve mention (for example, Bourdieu 1977; Lancaster 1981). But Gellner and the interpretivists represent two poles of what I suspect, for slightly different reasons than Combs-Schilling (1982), is a "false dichotomy."

\section{Yemeni tribalism and segmentation}

Most of the tribes of Upper Yemen belong to one or the other of two larger sets, Hāshid and Bakill, which between them constitute a larger set still, named Hamdān. The pair of names is pre-Islamic, and for at least a millennium has provided an axis of reported conflict. It is now said proverbially of two men at serious odds that "there is between them what there is between Hāshid and Bakîl." In practice, relations between men of a tribe from one set and those of a tribe from the other may be cordial, hostile, or quite unmarked. The constituent tribes of Hāshid and Bakil are territorial entities whose extent changes only slowly over time, and the borders between tribes are usually closely defined. The geographical extent and the population of these tribes, of which about seven are Hāshidi and 14 Bakīlī, both vary from case to case, as they do from section to section within one tribe. These variations by themselves should dispel any temptation to look for a balance of power; so too should the extreme longevity of the system's major elements. ${ }^{5}$

The good standing of a tribe (its worth in the eyes of others and its "value" in the system) is expressed in terms of sharaf: roughly, "honor as presented to the outside world." The name of 
the tribe or section (that of its "ancestor") is the da' $\bar{i}$ or da'wah, the "summons" that calls men to act in defense of their common honor or to enlarge that honor in some common exploit. The maintenance of sharaf, or "honor projected," depends upon the protection of 'and, or "honor defended." These terms are situated against each other within a simple structure which, for those who think diagrammatically, can be sketched as shown in Figure 1.6 Honor is the quality par excellence that can only exist in opposition. A tribesman cannot have honor by himself (in the Yemeni case he needs someone to defend it from), nor can a tribe or section, and sections or tribes have little substance apart from this honor that their members share. The same diagram thus applies to each level of the tribal classification, from the individual arms-bearing man upward.

Sections are not opposed to the tribes they form part of. They are opposed to other sections, just as tribes are opposed to tribes and Hāashid to Bakīl. The elements of the system acquire their value from the structure, without which they are only spaces on the map (a section by itself really is like the clap of one hand), and the notion of segmentation simply describes this.

It happens that in the Yemeni version the protected space on which sharaf depends is often identified with physical space: that is, with territory. Borders are thus a marked element, but there are others. The honor of a tribe is at stake not only in assaults on the borders, but in assaults on whatever those borders contain and on members of the tribe or their dependants wherever they may be; in breaches of the peace by outsiders in tribal territory, even if the tribe's members are in no way directly involved; in offenses against those whom the tribe protects (for example, descendants of the Prophet, certain families of "judges," "weak" people such as traders); and in offenses against protected events or places (for example, markets and certain towns). ${ }^{7}$ In any of these circumstances the "summons" of the collective name may be invoked.

A man whose arable land, for instance, is violated by outsiders may call on his "brothers" in the tribe or section for support. In practice numbers of such men (not by any means all of them) will often fight alongside him, although they have no personal interest whatever in his farm land or what it produces. Nor do those who turn out in support of the man attacked always have any personal link with him such as kinship, property, or a shared commitment to some other project. Men act to restore the "inviolability" of their tribe's territory (hurmat al-watan).

\section{SHARAF}

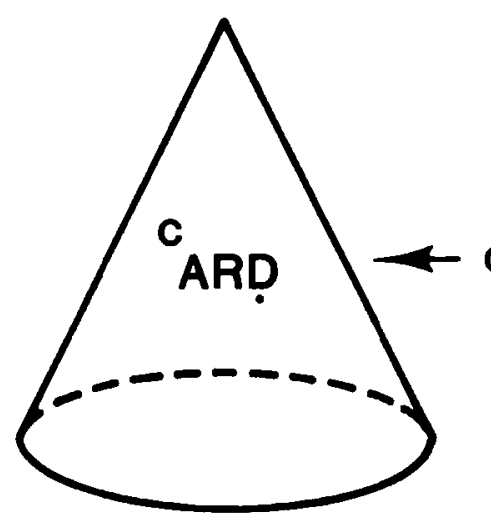

protected space

\section{SHARAF}

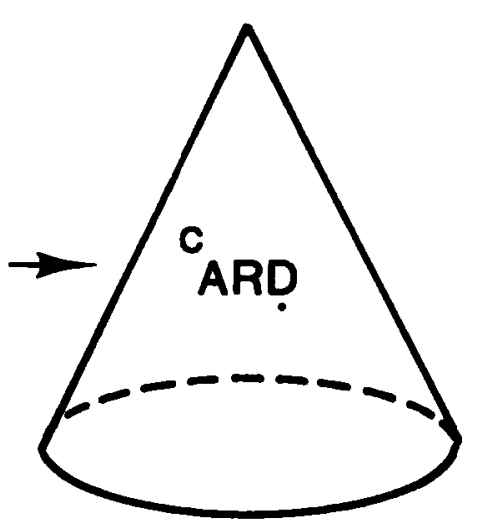

protected space

Figure 1. 
That inviolability is an aspect of the card (roughly, "honor as defended") on which the tribe's good standing rests and in which the 'ard of the tribe's members is in some measure contained.

We have said nothing about corporate or cohesive groups, nothing yet about individual actors or discrete events. We have talked only of (conceptual) structures and of definitions. However, it might be noted that those structures, informed by balanced or complementary opposition, do not "emerge" from interaction or from bargaining. They are not the product of individual actions. As we shall see, individual actions presuppose them. The structures have precisely the quality of extériorite with respect to the individual that anthropology is used to dealing with. Without opposition of formal equivalents there is no sharaf, without sharaf there is no such entity as a section or tribe (or even a tribesman), and without the opposition of such elements to each other being brought to consciousness there is, in a segmentary world, no "significance" (Meeker 1976, Pt. 1: 246, 253, 256). Men's actions would be meaningless or, to put the point more exactly, a whole range of actions would no longer be possible.

There remains a disjunction between what people do and say (the problem of "ideology"), but the disjunction itself is intelligible. Sections or tribes are elements in a structure of collective honor, and it is hardly surprising that hypothetical questions by outsiders (people against whom, in the abstract, honor is defended or projected) are answered with a certain uniformity, particularly when the terms of the question preempt the answer. If one asks, "What happens in a killing between Hāshid and Bakill"' the answer will often come back in the familiar terms of cohesion and solidarity. The crux of the matter in practice is that, for example, a man from $A$, which happens to be in Hāshid, killing a man from B, which happens to be in Bakīl, is not necessarily taken up as "a killing between Hāshid and Bakīl." Almost anything could happen. It is not that the relevant local concepts are "malleable" (Rosen 1979:46), but that they do not specify their own application, and this application is highly variable.

It is important to note here that, even in the most abstract terms, the segmentary structure of shared honor does not imply unfailing cohesion-first, because each lower-order element (man, family, section) is a particular locus of honor, which may be invoked against others at the same level and thus preempt an appeal to a higher-order set; and second, because honor requires not that one support one's "brothers" in all circumstances, but that one acts to uphold their rights and the rights of the collectivity. The rhetoric invoked is of moral equilibrium ( $\mathrm{mi}$ zăn, balance), whereby action is undertaken purportedly to restore the status quo ante of those wronged. ${ }^{8}$ Who is to say in a given case where the right and wrong lie? The possibility exists, and in practice is often exploited, of saying that our people are in the wrong and that honor demands we ignore the collective summons or even oppose it. They may then say that we are acting dishonorably, but we can claim the same of them. The practical problems that ensue may be more or less severe, but there is no contradiction felt by those who do so in refusing support to one's tribal brothers.

If a contradiction is to be discerned at all, it affects only the higher-order set whose name is invoked unsuccessfully, but this is at a level where, as it were, no one lives. A claim to support may be made in terms of tribe $X$ : as soon as some group of men says, "We in $X_{1}$ see things differently," then $X$, which abstractly denotes both the claimants and those refusing to support them, becomes only a word. The power of that word depends on who uses it when and for what perceived ends.

As perhaps in most societies, there is a tendency to hold, without looking too closely at the facts of the case, that "our" people are in the right as against outsiders—a spirit of tribal solidarity right or wrong, of the "clannishness," or cohesive drive against others, called casabiyyah. No doubt there is a corresponding tendency for events to follow the lines of tribal classification (we shall return to what is meant by this), but it is only a tendency. In a given case, and from the point of view of behavior or of observation, almost anything may happen. From the point of view of action or of meaning one seldom escapes the notion of segmentation or the particular categories it informs. 
There is not the space here to do much more than assert that segmentarism in the Yemeni case has an oddly inclusive power. Whatever is put into the system emerges looking like tribalism: foreign intervention by Saudi Arabia, Egypt, and Britain in the 1960s and by the Saudis, South Yemen, Iraq, and Libya and a half-dozen other powers since then; the rise of more local political groups; and disputes over day-to-day running of such things as the trucking business have all acquired segmentary form (Dresch 1984b:171-172).

To be clear about what is meant by this let us go back to the locus classicus. Segmentation is apparent first of all in a process of (situational) definition:

Any segment sees itself as an independent unit in relation to another segment of the same section, but sees both segments as a unity in relation to another section; and a section which from the point of view of its members comprises opposed segments is seen by members of other sections as an unsegmented unit [Evans-Pritchard 1974 [1940]:147|.

We are all $X$ in relation to $Y$, but $X_{1}$ in relation to $X_{2}$; and from the viewpoint of $Y^{\prime} s$ members all of us are $X$, while from that of $X_{2}$ 's we are all $X_{1}$. Elements at the same level are formally equal and are defined by mutual contradistinction, that is, by balanced opposition. They are characteristically not defined in isolation or by reference to the set they fall in.

To invoke inclusion or hierarchy one has to break with the rhetoric of collective identity and invoke that of "leaders" (more properly "guarantors," Dresch 1981:81, 1984a:40,45) or break with tribal rhetoric altogether, as was continually done by Yemeni tribalism's historical complement, the Zaydi Imamate (cf. Dresch 1981:82, 1984b:164). Within tribal rhetoric one constantly encounters a model or "ideology" (above), much as was the case among the Nuer (Evans-Pritchard 1974 [1940]:144): the named elements of the classification are spoken of as acting in predictable ways. In practice things are less tidy. The names invoked in particular circumstances cannot always be guessed in advance and the classification is not "realized" as a whole; but, whichever names are evoked, the structural principles just outlined still apply.

That, perhaps, is to say no more than that tribalism still flourishes in Upper Yemen more than in most places. A more basic point is at issue, though. The particular patterns of categories and the courses that events take are extremely variable, so that an empirical approach leaves us with a long list of separate oddities. The confusion is not resolved by a focus on individuals: the list of oddities simply grows longer. The obvious parallel (in method, be it said, not ethnography) is with something like the Indian caste system, where it is not useful even to ask how many elements of the system there are, where the specificity of each case cuts it off from the next in a neighboring village, but where a principle can nonetheless be found that is common to different instances (Dumont 1970). The principle to be found in the case of Middle Eastern tribalism is balanced opposition. Since opposition occurs at more than one level, the formulation we require is that found in the notion of segmentation.

\section{the course of events}

The acid test of lineage theory (the "social masses" view of society) was what happened in conflict. It should by now be a commonplace that conflict and opposition are not the same thing (Pocock 1961:72-79). Conflict is only one type of event that may occur along the axis that a particular opposition forms, but conflict is what people in these societies themselves often dwell on and it provides an instructive case. In lineage theory there was supposed to be a "massing effect":

In any opposition [what is meant here is surely conflict) between parties $A$ and $B$, all those more closely related to $A$ than to $B$ will stand with $A$ against $B$, and vice versa. Segments are pitted against equivalent segments: any opposition between groups (or members thereof) expands automatically to opposition between the largest equivalent lineages of which the contestants are respectively members ISahlins $1961: 332]$. 
In the case at hand, this massing effect does not occur reliably; nor, indeed, does the segmentary structure allow one to predict particular events at all. ${ }^{9}$ The implications drawn out in the above passage are, however, present and we must consider how they are dealt with.

A distinction should first be made, to avoid confusion, between the sets of men that tribal names denote and the (transient) groups of men who act in those names and are acted on. ${ }^{10}$ The identity conditions of the sets and of the groups are surely different, and the two types of element are distinct in practice: for one thing, they are of different sizes. A war may be spoken of by those involved as being between two tribes, or even between Häshid and Bakill, but the men doing the fighting usually number dozens, and only seldom even hundreds, while the sets in whose names they fight comprise tens of thousands. "Most of those who fall within the two opposed sets will take little or no part. But even small-scale fighting exemplifies the opposition between the two tribes and hence demonstrates those tribes' honor, which itself gives events their sense. The types of events are specified in part by the structure, but the course of events is not and may cross the tribal categories in almost any direction.

Let us take a case. Banī Ṣuraym and al-'Uṣaymāt are both Ḥāshid tribes, while Sufyān is part of Bakīl. A man from al-'Ușaymāt, who made a living from the transport of firewood by truck, was involved in an accident within Sufyān's territory. Certain shaykhs of al-'Ușaymãt wrote to those of Sufyăn demanding to know who was responsible. No satisfactory answer was received, and roadblocks were set up in al-'Uṣaymāt's territory to impound trucks from Sufyān. Men from Sufyān then set up roadblocks in their own territory and impounded trucks, not only from al'Uṣaymāt, but also from Banī Șuraym (both the latter are Hāshidi). Roadblocks next appeared in Bani Șuraym but the trucks impounded there were from al-'Uṣaymāt, whom the Șuraymīs held responsible for the dispute, and not from Sufyãn: $X_{1}$ at odds with $Y_{1}$ turned on $X_{2}$, which is not unusual. Note, though, that $X_{1}$ and $Y_{1}$ did not combine against $X_{2}$, because there are no readily available terms in which to do so. One would have to shift register, as it were, and invoke a nontribal identity.

Things got seriously out of hand when a Șuraymī fired on an "Ușaymī truck in which there happened to be women (a great "disgrace" or "insult," 'ayb) and large numbers of al-'Uṣaymāt gathered for war. A delegation of shaykhs from elsewhere in Häshid intervened between al'Uṣaymāt and Banī Șuraym and arranged a truce. The dispute between members of al-Ụsaymāt and Sufyān (potentially between Hāshid and Bakil) was all but forgotten and was eventually settled between individual families.

At the center of any wider dispute, then, are the particular antagonists-individuals or particular families. Around them forms a pattern of pressures. What the pattern will be in a given case depends on any number of considerations besides "clannishness," and the pattern is in part negotiable. Let us see how these negotiations might proceed.

Two particular gestures-giving rifles and giving slaughter-beasts ('aqã'ir)—are employed in circumstances of appeasement, of forming pledges, and of demanding help. ${ }^{12}$ For example, if a man from one tribe kilis a man from another, the killer's people should immediately send the victim's people a bull. If the bull is not given, then the victim's people have little option but to seek revenge: insult has been added to injury, and the victim's people are dishonored ("their faces are blackened," suwwad wujüh-hum). If a bull is offered and accepted (which it may not be), the way is open for settlement of the blood-debt by cash compensation. These protocols of appeasement may break down at any point. Nevertheless, they provide the possibility of settling a blood-debt peacefully, over whatever structural distance, between "the killer's people" and "the victim's people" ( $a h / a l$-qātil and $a h l a l$-qatil). These terms are of indeterminate reference in Yemeni Arabic and are deliberately left vague in translation.

If one man wounds another, the culprit's people should offer the victim's people a rifle: a "rifle of right or justice" (bunduq al-șawäb) or a "rifle of patience" (bunduq al-șabr). If the rifle is offered and accepted (which, again, it may not be), then the victim's people acquire right of judgment. They are honor-bound not to seek revenge while the rifle is held, and they can, in 
theory, name the amends due them. Again, the proceedings may break down at any point. If they do, then the rifle is handed back, as it is if negotiations are concluded satisfactorily. The link persists only as long as the token is retained, but the possibility exists of sustaining the link and concluding the matter peacefully.

Even in cases of wounding, a slaughter-beast ('aqirah, maqsad) often precedes or accompanies cash compensation. In serious cases, the cash may be waived by the victim's people but the slaughter-beasts cannot, and in all cases the protocols of appeasement are, in one form or another, needed. Without the beast or the token there is no binding relation ('alqah), but only a debt to be paid in blood. The beast or the rifle denies the insult, and it is the insult (not the injury itself) that besmirches honor. The seriousness of the offense is identical with the extent to which honor is besmirched (or "broken," as the Yemenis say), and this is not simply given by the nature of the offense at the time it occurs but emerges in the period after it.

The segmentary, tribal structure is of honor, not of cohesive groups. Any two tribesmen will be at a certain structural distance from each other, and the two points they occupy in the classification define an axis of opposition. If they happen to belong to different tribes, then the situation is as shown in Figure 2.

This is an abstract relation and a similar line can be drawn between any two men, whether or not they are at odds. If a conflict does arise between the two men in the diagram and one inflicts a loss on the other, then there is an implication that the honor of their respective villages, sections, and tribes is at stake. The implication may be ignored, taken up, or denied, according to circumstance. If no recent antagonism has set the two tribes at odds, and if the protocols of appeasement are now applied promptly, the two antagonists and their families may settle the matter without the issue of wider involvement ever being raised. If previous antagonism has, as it were, primed the system, or if the present dispute is not composed easily, then the abstract implication of wide involvement may be vigorously taken up. In the first case, "the victim's people" are a tiny group, perhaps the man's immediate kin. In the second case, "the victim's people $\mathrm{e}^{\prime \prime}$ may be his whole tribe. It is important to note that these different outcomes can derive from what, in our view of things, is the same offense. ${ }^{13}$

The elements of the tribal system (hardly more than names for most purposes) are opposed to each other in terms of honor. The higher-order elements are more "significant" (more honor

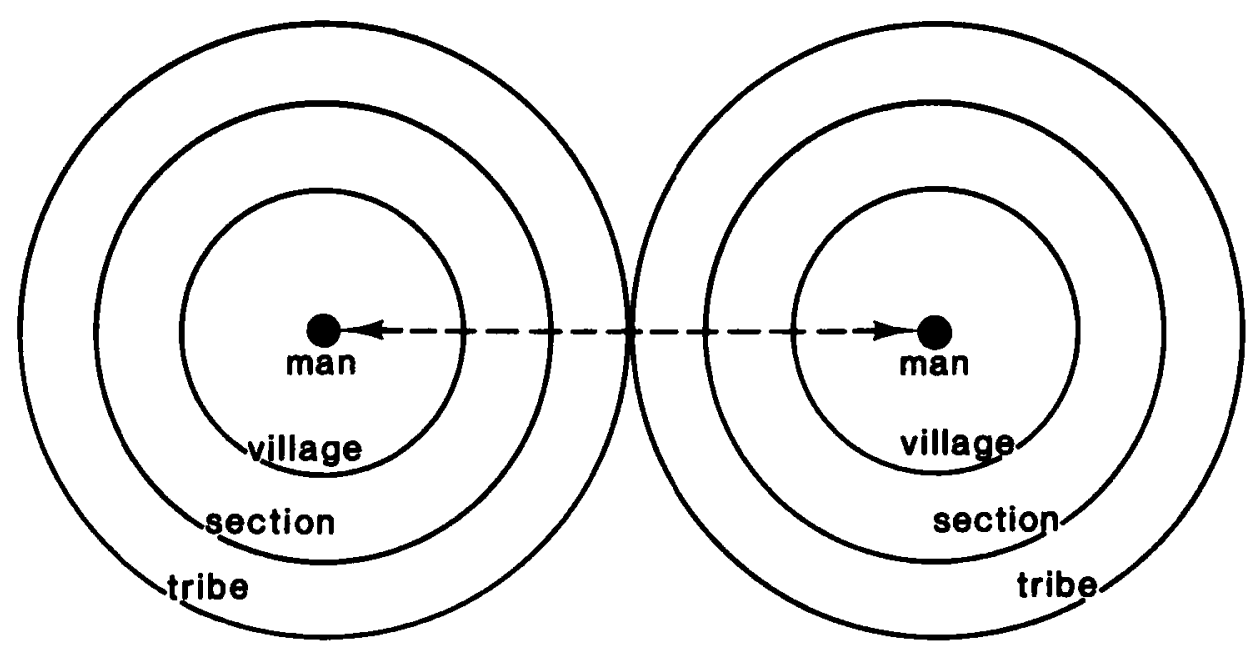

Figure 2 . 
is at stake, if you like) than those of lower orders:

the rhetoric is 'elevated' as one rises in the genealogy. For two neighboring lower [order] segments may express their sharaf in feud, but the greater, more glorious sharaf of tribal segments must be expressed on a larger scale, that is, warfare |Meeker 1976, Pt. 1:2551.

This is not, of course, directly to do with numbers: a "war between Hãshid and Bakîl "may be highly significant in these terms, and remembered as such for decades, for all that the number of men who fought in it was tiny. The significance of the units invoked and the significance of the initial event leading to confrontation may also be linked. A dispute where honor is dramatically at stake (one involving women, a protected person, a market, or some other marked element) tends to expand to fill the available space: that is, the dispute between $A$ of Hāshid and B of Bakīl, for example, is more likely to become "a dispute between Hāshid and Bakīl." On the other hand, if a dispute between $A$ and $B$ is characterized for other reasons as being between Hāashid and Bakīl (if antagonism already exists, or if public opinion is manipulated for their own ends by some of those involved) then the dispute itself becomes more serious: the amends sought are higher and the settlement is more difficult. ${ }^{14}$

Negotiation can also determine not only how much honor is at stake but whose-not only how wide the circles invoked on our diagram (Figure 2), but which segments and arcs. If a man from Khiyār in Banī Suraym (a Hāshid tribe) is killed by a man from 'lyāl 'Abdillāh in Arḥab (a Bakil tribe), his immediate kin may at once take up arms. If there has been a recent antagonism along a closely parallel axis, then a wider confrontation may ensue at once, with others from 'lyāl 'Abdillāh and Khiyār involved, or roadblocks being thrown up elsewhere in Bani Șuraym to trap anyone from Arhab, or fighting even breaking out along the common border of two other tribes, one from Hāshid and one from Bakîl. The numbers actively committed may remain small, but the spread of involvement can be very wide. More usually, though, events spread slowly. Khiyār may seek help from other sections of Banī Șuraym (from Wãda'ah, Banī Mālik, and so on) at a specially convened meeting or at market on market day. The shaykhs of Khiyār might proffer the shaykhs of these other sections rifles, called "rifles of obligation" (banādiq altalzim) or "rifles of brotherhood" (banādiq al-ikhā'). If such tokens are accepted, then for as long as they are held they denote a relation ("alqah) considered binding in a way that simply sharing an eponym is not. To impose a binding obligation more pressingly the shaykhs of Khiyār might kill a bull at market or at a meeting of the tribe or at the door of a particular shaykh whose help they wanted.

A rifle can be handed back at any point, thus severing the link, and the obligation imposed by the slaughter of a bull can be lifted by returning and slaughtering a beast of about the same value (Serjeant 1977:245). There is nothing predetermined about the outcome. The men of each section (or usually their more prominent shaykhs) can decide as they see fit. On the killer's side (in clyāl 'Abdillāh of Arḥab in Bakīl) a similar process of canvassing and giving or refusing support takes place, producing as irregular a pattern as on the victim's side (in Khiyār of Bani Suraym in Hāshid).

The killer's people may send the victim's people a bull, opening negotiations for settlement and cutting short the search for allies on both sides. The victim's people, on the other hand, may pass a rifle, called bunduq al-'ard, to the shaykh of the killer's own section or tribe. If this is accepted by the shaykhs of Arhab, then they accept that 'tyāl 'Abdillāh are in the wrong and undertake to bring pressure on them; if it is accepted by those of clyāl "Abdillahh, they accept that their own man (the killer) is wrong, and they undertake to chase him up (yuhawwir-hu) on behalf of his structurally distant antagonists. The axis of dispute becomes the axis of settlement.

If a dispute expands, for whatever reason, then men may find themselves involved, whether or not they wish it, because of the structural implications linking them with those principally at odds. The victim's people in Banī Șuraym may, for instance, impound trucks not only from 'lyāl cAbdillāh (the killer's particular section), but from men who belong to other sections of Arhab 
(Bani 'Alī, for instance) or even from men who belong to other tribes of Bakīl, such as Sufyān. Bani 'Ali, or whoever it may be, find themselves vulnerable through no direct action of their own. They are free, however, to opt out and deny any part in the widening antagonism by giving the shaykhs of Khiyār "rifles which clear them" (banādiq al-șafw). If the rifles are accepted, a link is formed. Banī 'Ali undertake not to support 'lyăl "Abdillāh in the dispute at hand and they cease to be liable to attack by those who hold the rifles. The same denials may be made on the victim's side so that, as the dispute widens, certain sections of Bani Suraym, and beyond that certain tribes of Hāshid, may stand aside by giving rifles to clyāl cAbdillāh or to Arḥab. The rifles may not be accepted. So long as the rifles are held the situation is redefined.

The exchanges of bulls and rifles touched on so far may themselves be challenged. Members of one section may give a rifle (perhaps "of companionship" or "of brotherhood") to members of a second section, and the members of a third section may then proffer further rifles to claim, in effect, that the first rifle was accepted wrongly and should now be handed back to sever the relation. Negotiations may be a complex tangle of bids and counterbids from several parties. The complexity is increased by the possibility of redefining what the last move meant: for example, a rifle that was given "for "ard (to have men intervene with their fellows on our behalf)" may come to be spoken of as "for right," giving those who accepted it-now tacitly redefined as both our particular antagonists and their fellows - right of judgment and assuring us that they will not attack us. These alignments are necessarily arrived at by individuals, acting as guarantors (dumanā', kufalä'), who form specific ties with those they speak for and with each other, again exchanging rifles as tokens.

Such ties cut across the explicit categories of tribal classification in several directions. The course events take does so too. The "massing effect," whereby a conflict between individuals should actively involve all the members of the largest opposed sets they fall in, does not occur reliably. Parts of those sets and their subsets may be excluded explicitly. Others may simply not be involved. As we saw at the outset, members of $X_{1}$ at odds with $Y_{1}$ may set on $X_{2}$. Lineage theory is contradicted by the course events take at one turn after another, and from that theory's point of view all appears confusion. What are we left with?

\section{structure and action}

Groups may form or combine in a great many patterns other than those tribal classification suggests to us. Exchanges of bulls and rifles can result in a particular (abstract) opposition providing the axis for conflict, alliance, or downright indifference. However, one does not just give rifles to anyone. Rifles of "brotherhood" are given precisely to one's "brothers," as the segmentary system defines them, to demand support from them or to pledge support; one gives rifles of card to one's antagonist's "brothers," again as defined by the system, to have them bring pressure on him to make amends; outsiders are given rifles which clear one, precisely because of a man's implication in the actions of his "brothers," whom the structure defines. Without the structure all of these different actions would, strictly speaking, be meaningless. They would no more be action than is Brownian motion or the way the wind blows. The structure that action presupposes is not itself negotiated. The categories it informs are there before a sequence of events begins, and, whatever course events take, their significance derives in large part from the structure.

How is this connection to be understood? The original formulation of the idea of segmentation was certainly concerned with political practice - it was intended to make that practice intelligible-mbut it was not a summary of political events or relations as such:

political relations ... are best stated as tendencies to conform to certain values in certain situations, and the value is determined by the structural relationships of the persons who compose the situation IEvansPritchard 1974 [1940]:137]. 
This is not a causal model that tells one reliably what will happen next. ${ }^{15}$ People do not behave, they act (Dumont 1970:6), and the approach in terms of segmentation characterizes the forms of action available. To do this it breaks down what in practice is a simultaneity. If we begin, in a fairly stable system, with observing political events, then political relations (which those events exemplify) precede them logically, values (as Evans-Pritchard notes here) are prior to political relations, structural relationships precede them, and complementary or balanced opposition, which specifies the form of those structural relationships, precedes or underlies the whole sequence. ${ }^{16}$

To equate complementary opposition with "a pattern of loyalty and alliance," as Salzman (1978:53) and most authors do, is to collapse the argument and to miss its worth. Segmentation is then reduced to a summary of empirical observations. Either it is a statistical gloss on a body of measurable events or a mechanical model of how these events are caused. In either case we find ourselves dealing again with behavior rather than with action: that is, with human events stripped of the values by which they were constituted in the first place. Such a reading is not, I think, true to the original (other readers will have their own view of Evans-Pritchard), and certainly it is unsatisfactory as a means of approaching ethnography. Collapsing the argument to produce empiricism (if that term be excused for brevity) is what lineage theory did.

The lesson of postwar ethnography elsewhere in the world is surely that "structure" is not to be looked for in only one empirical instance. Instead, a purely formal relation (in this case, balanced opposition) is looked for that is congruent with a number of often partial and informal local descriptions. The same principle might then appear in the ordering of categories or of groups, in what people do on one occasion and say on another, in the large scale settings of whole tribes or on the smaller scale of families and individuals. The point is to isolate the form of such ties, regardless of the elements they join in different cases, and thus to isolate the conditions for their making sense to those involved. The most promising line, therefore, is to ask not why specific events take the course they do, but rather what sorts of events are possibleto look not at actors or groups, but at forms of action. Eickelman makes a similar point as follows:

The relatively stable element in this type of social structure is not the patterning of relations between persons or groups of persons, as is suggested by many definitions of social structure. Rather, it is the culturally accepted means by which persons contract and maintain dyadic bonds and obligations with one another IEickelman 1976:901.

All that needs to be added is that these "means" are themselves an expression of structure, just as transient relations are, and that whether or not these relations are between persons or groups, or for that matter between sets, becomes secondary.

Groups, of course, emerge from interaction: little knots of men one could count and observe. There is no need, though, to mistake the groups for the sets in whose names they act. Both demonstrate segmentation, but neither can be equated with the structure itself. The temptation to downgrade segmentation to the status of "ideology" derives from identifying the structure with one of its instances - with a set of explicit categories, for instance, or with an alignment of groups at a given time. The "refutation" of segmentation can then only take the form of the complaint, in the anthropology of another area and an earlier period, that marriage circles do not always close.

The complaint is, of course, entirely justified if by structure one means "actually existing relations" that are supposedly "observable" (Radcliffe-Brown 1965:190). Moroccan tribalism is dealt with by Eickelman very soundly in those terms. He documents the lack of fit between events and the tribal classification, much as one might do for Yemen, shows how a colonial administration "froze" tribes into more stable divisions than they had been, and stresses the incomplete knowledge of those divisions most tribesmen have. He concludes that

social structure in Morocco, both urban and tribal/rural, is based upon the ordered relationships not of groups of persons, but of persons ... Tribes, tribal sections, local communities, quarters, agnatic descent 
and so on merely constitute frameworks by means of which persons relate to each other [Eickelman 1976:120|.

This is surely true, given a certain view of what social structure must be. However, the result is just as surely a blockage. After all, so much of Moroccan history consists of tribes (these "frameworks" of relation) displacing one another in spectacular fashion (see, for example, Dunn 1973), and we would have no means to describe this. Even the local system Eickelman himself is discussing becomes very hard to deal with. We are told, for example, that "sections" (the next level down from "tribes") were fairly long-lived identities and "fulfilled defensive functions" in the building of forts (Eickelman 1976:113), which is unusual enough in the context of Middle Eastern tribalism for one to want to know more. But the tribes of the Tadla plain slip from view as arbitrarily as they came, and with them the whole phenomenon of tribalism.

The stress on individual actors was welcomed as a reaction to the excesses of lineage theory. Where tribes and sections were depicted as solidary masses that pushed and pulled in predictable fashion, individuals could only be automata. The reaction, however, leaves us at the other extreme, where there are only individuals, and vertiginously free ones at that. What sorts of actions are then available to them (let alone compelling for them) that are not so for all of us?

From the point of view of people within the system, or indeed of those analyzing it from outside, the tribal divisions may appear as something like a "framework" (Eickelman 1976:120; Rosen 1979:25), but the relation of action to the notion of segmentation is more intimate than this image suggests. The actor himself (the tribesman) is constituted by the possession of honor, which itself, as we have seen, is a segmentary quality. ${ }^{17}$ He is not just a point, with position but no cultural extent, around which meaning coalesces. Far from being given, the actor is constituted in accord with the same structural principle as the categories with which he works and the forms of action available to him. People may alter their place in the set of categories, but they cannot be without a place. To be a tribesman is to be part of a set opposed to other sets. If the opposition is expressed at some point as conflict, then one has various options, as we have seen, but each option is itself informed by the notion of segmentation, just as is the event that requires that one choose between options in the first place.

Furthermore, actions are meaningful in something more than the sense of being glossed (by the actor or others) ex post facto. The intent of the action is integral to it and itself is informed by the notion of segmentation. It is not the case, for example, that a man's arm is extended with a rifle in his hand that is grasped by another man whom the analyst then discerns as part of a set related somehow to that which the first man falls in. One "gives a rifle of patience." That itself is the action. The identities of the giver and receiver are inseparably part of its intent, and their (structural) relation is informed by opposition. Without this there would be no action, but only a physical event. If the meaning of the first act is changed (the rifle's significance is redefined, which itself is an action), then the same argument applies to the change as to the initial gesture.

Isolating the actor as a key to analysis leaves society as a residue to be built up by the actors' efforts. Social structure, in rather Radcliffe-Brown's sense, then appears to be accounted for by observing these actors, while meaning (or perhaps culture) provides the terms in which actors operate. The alert writer using this paradigm is soon forced to speak of conceptual and relational planes that are somehow distinct (for example, Rosen 1979:27). The actor, robbed of either kind of attribute, is supposed somehow to combine these, and "action" becomes a loose metaphor for the process of combination. The problem is that the relational plane is not only conceptualized but works through concepts, and the concepts have no sense without relations. Meaning permeates both levels. ${ }^{18}$ The problem is at its most acute where individuals act, not simply against each other (taking others on one by one in dyadic relations), but with reference to terms that denote collectivities: men gather, for instance, in response to a tribal name. One cannot describe this in dyadic terms unless one pole of each dyad is the nonexistent "ancestor" of the tribe. 


\section{problems of change}

Rosen, though also stressing individuals and their weblike networks, draws attention to a further problem that arises with the same view of social structure as that used by Eickelman. Two tribes, the Ait Yussi (whose explicit divisions usually "provide a framework, . . . a lexicon of possible affiliations upon which individuals can draw in forming their personal networks" (Rosen 1979:25) and the Ait Seghoushen (presumably similar), fell out over the activities of a third tribe who may have settled in the area under the aegis of Ait Yussi but in the course of the dispute now claimed to be Ait Seghoushen (Rosen 1979:53-57). The importance of tribal identity is here not in doubt at all, but the identities, perhaps not very clear to start with, change.

Let us say that 'lyāl 'Abdillāh of Arhab (Bakīl) come off worse in their encounter with Khiyār of Banī Șuraym (Hāshid). They appeal for support to the other sections of Arhab and little help is forthcoming. Their last resort is to cease to be Arhabī. If the rest of Bakīl provides no satisfaction, they may cease to be Bakīī. They then go to a Hāshid tribe (usually one goes to the neighboring tribe, which in this case would be Khärif) and they proffer bulls to be slaughtered in the Hāshid tribe's market. If the bulls are accepted, then "lyāl "Abdillāh "become brother" (yukhāwū) to Hāshid, and become in fact part of the tribe who accept their bulls. Arhab should come after them and slaughter further bulls to revoke this redefinition, but changes do sometimes occur that are not revoked. ${ }^{19}$

One could not say, as Rosen says of the Moroccan case, that "As a vehicle for gaining allies, there was no compunction on anyone's part about claiming alternative and mutually contradictory tribal identities" (Rosen 1979:56). Such changes are not undertaken lightly (one can too easily fall between two stools and have no allies). But more important for the present purpose is the analytical point that the identities themselves are not contradictory, only the claims: the concepts or categories themselves are not negotiable, but only who or what falls in which of them. The categories and the structure preexist the actions. A new set of actions (a pattern of alliance) that does contradict the original categories becomes possible only with explicit redefinition.

The larger system of categories remains intact: Hāshid remains opposed to Bakīl, and Banī Suraym or Khārif to Arhab. Only an element of one set is reassigned to another set. Furthermore, even if we focus on explicit changes at the level redefinition takes place, the structural principle that informs the new disposition is the same as that informing the old--balanced opposition. One tribe is opposed to the other, though a section that was part of the first is now part of the second. The "concept of genealogical relatedness" (which specifies identity in a tribe and situates sections or tribes with respect to each other in accord with the notion of segmentation) is not "an inherently malleable basis for conceptualizing and rationalizing a network that will have been built up through a number of dyadic bonds" (Rosen 1979:105). It is the logical and cultural ground for such bonds to be formed, severed, or even recognized. It is all that gives the change its meaning. A section severs its definitional ties with a tribe because its members feel themselves wronged. The honor of a tribe requires that "brothers" uphold each other's claims to right and the right of the tribe itself. The honor of the tribe that a section leaves is thus called into question and the honor of the tribe it joins is affirmed before others, hence the moral imperative (usually felt in practice) for the first tribe to retrieve its seceding section.

We said earlier that from the point of view of behavior or observation almost anything could happen, while from that of action and meaning one seldom escaped the notion of segmentation. This is a case in point. We said also that there is a "tendency" for events to follow the lines of tribal classification. If one wanted a measure of that tendency, then it would have to be the number of times that different men of $X$ (however many or few) combined against different men of $Y$, as compared with combinations of men from $X$ and $Y$ against other men from $X$. The ratio does not have to be large for us to discern a "segmentary operator." 20 Think then about what the denominator of our fraction would be. If men of $X$ and $Y$ combine against other men 
from $X$, in what terms would they do so? Not segmentary terms, plainly, because there is no identity in the system shared by some members of $X$ and some of $Y$, but not by others. ${ }^{21}$ Where the categories are unavoidably put to the test (which seldom happens) and are found wanting, they are reordered and the identities redefined. The apparently arbitrary course of events, as measured by the observer's categories, is evidence against lineage theory. The fact that a change is made in the tribesmen's categories is an equally striking demonstration of segmentation's importance.

The Yemeni examples touched on earlier show that the "massing effect" does not occur reliably: not all of those closer to A than to B support A, nor all of those closer to B support B. The converse principle, however, that of "segmental limitation" (Bohannan 1958:50), remained intact: even if not all of those closer to A or B become involved, at least no one is involved beyond the smallest set that contains $A$ and $B$ together. From a certain point of view, this principle can also be contravened in practice. When this happens, the categories of the tribal system must be consciously altered.

Let us say that 'lyāl 'Abdillāh and Banī cAlī (both of them from Arḥab) fall out with each other and no other tribe is involved at all. It may be that 'lyāl 'Abdillāh, despairing of their claim being settled, "become brother" to the neighboring Hāshid tribe of Khārif. If the original squabble is not halted, 'lyāl 'Abdillāh now have a claim (and a very strong one) to support from Khärif. Banī 'Alī have a claim on Arhab. The two tribes of Khãrif and Arḥab may be set at odds, and behind them lie all of Hāshid on the one hand and Bakīl on the other. In other words, a conflict between $Y_{1}$ and $Y_{2}$ may provoke a conflict between $Y$ and $X$; but it can do so precisely because those terms have been shifted in an ordered manner.

Again, all of this can only make sense in terms of a certain concept of honor, a certain type of relation that is described as balanced opposition. The elements may shift position but the type of relation between them is always the same: formally equal elements are defined by contradistinction, and formal inequality is admissible only in terms of the inclusion of subsets in larger sets. The problems of analysis have little to do with the distinction between individuals and groups. They have a great deal to do with that between specific ties and general principles. Indeed, it is only by abstracting the general principles that we can describe the forms of change.

conclusion

I have touched at a number of points on writings about Morocco, and have myself used material from Yemen. North Africa and South Arabia are in some respects different. The Yemeni tribal system is characterized by remarkable geographical stability over long periods, for instance, while the Moroccan system exhibits as remarkable a degree of change (this makes the problems touched on here more pressing in the Moroccan case, not less so). ${ }^{22}$ In many other respects, the differences are not so marked. In both cases one cannot successfully deal in terms of solidary groups. In both, the replacement of specific links between groups by links between individuals seems problematic.

No one would claim (except perhaps Gellner 1969:42) that segmentation was by any means the only principle at work in tribal society; no one would claim that the interpretive position contained only the stress on persons dealt with here. Yet a certain link with past thought seems missing. The approach shared by Eickelman, Rosen, Geertz, and others (Eickelman 1984:285) did not rise fully formed from a world bereft of previous anthropology, and the resources available are perhaps richer than at first appears. Segmentary lineage theory has to go, but to reject the notion of segmentation along with it seems retrograde. Far from being incompatible with an interpretive position, and thus due to be superseded, it provides an essential aid to the project of delineating "the implicit assumptions which people themselves make" (Eickelman 1984:286). To reject it is, in effect, to reject part of those assumptions, the part that constitutes tribalism as any more than the lack of urban civility. 
Acknowledgments. Fieldwork in Yemen during 1983 was supported by a research grant from the United Kingdom SSRC.

An earlier version of this paper was read at University of California-Santa Barbara and at Michigan in March 1984. Walter Edwards, Bruce Mannheim, Sherry Ortner, and Andrew Shryock were all kind enough to read and comment on a more recent draft. I am particularly grateful to Dave Edwards for his detailed suggestions. The faults remain my own.

'See particularly Gellner (1969:44), but the essential elements of this reading are already apparent in Middleton and Tait (1958), including the characterization of solidary groups as "corporate." This is not the place to pursue the question. However, Evans-Pritchard and Fortes are still often spoken of in the same breath (for example, Salzman 1978:54); it is a useful exercise to follow the term "corporate" through the Tallensi books and then search it out in the Nuer trilogy. They are very different.

As far as the Middle East is concerned, the joker in the pack is Peters' paper (1967), which no other work on the subject fails to mention, but which itself nowhere names the object of its criticism. Much of the argument therefore turns on a "virtual image," a byproduct of Peters' own position.

${ }^{2}$ There is one place, and I think one place only, in the book where balanced opposition and political equilibrium are equated (Evans-Pritchard 1974 [1940]:130, where "balanced hostility" and "equilibrium of opposition" are in apposition). The "people with few cattle" are being discussed, that is, those who cannot readily be beaten (organized Shilluk) or are not worth beating (tsetse-ridden Anuak). It is not that the Nuer push and these other people push back with equal force, but that force is seldom exerted at all.

${ }^{3}$ A similar point is made by Salzman (1979:123), who realizes that "lineages" are not an essential part even of lineage theory. His own analysis, however, continues to pursue "corporateness" $(1979: 122,1978)$. In fact corporateness in the strict sense is usually absent from Middle Eastern societies; its presence would always need to be established in a given case. If there really were corporate groups, then the idea of segmentation would not be so necessary in the first place (cf. Sahlins 1961:329).

${ }^{4}$ Eickelman (1984:286) complains of misplaced criticism that depicts the interpretive approach as concerned "merely" with dyadic networks and the like. Certainly there is more to the approach than that. However, the stress on persons and dyads is an impassably salient part of the project as formulated so far.

${ }^{5}$ For further information on the Yemeni tribal system north of San' ${ }^{\complement} \bar{a}^{\prime}$, see Dresch 1984a and 1984b. For a more general sketch of the elements of Yemeni society, see Serjeant 1977. By tribe I translate qabilah, which may admittedly be used on occasion of much smaller units but which usually refers to one of the twenty or so major elements. Some of these are very large. It would not be unusual to refer to Khawlān alṬiyāl as a "tribe" that itself contains several "tribes."

"See Meeker's very useful discussion of the problem (1976) and compare the present diagram with that which Meeker provides (1976, Pt. 1:255).

'For an outline of these different groups and instances see Rossi (1939:141-143), Serjeant (1977), and Dresch (1981:85, n. 15).

${ }^{8} \mathrm{~A}$ rhetoric of moral equilibrium is not, of course, the same thing as political equilibrium. At the same time it is a feature of Arab tribalism that explicit categories are rather seldom destroyed, no matter what displacement or diminution their members suffer: "the fate of Bajïla is a marvel, not the norm" (Crone 1980:23). The Berber case may very well be different.

The cultural presumption of formal "balance" is evident in several linguistic symmetries; for example, "ayb is both the "insult" committed by an offender and the "disgrace" his victim suffers, gharamah is both the "crime" of inflicting damage and the "cost" of amends. Note also "the killer's people" and "the victim's people" below.

${ }^{9}$ Sahlins is quoted here for the succinctness of his formulations. The theory of which they form part would certainly not apply to the Yemeni case.

${ }^{10}$ Evans-Pritchard uses the principle of opposition, says Dumont, but "he expresses it for the most part in the language of oppositions of fact, of conflict. In this sense his structure generally appears as tied to empirical circumstances" (Dumont 1970:41-42). Some of his key formulations are very likely to mislead: for example, "by social structure we mean relations between groups which have a high degree of consistency and constancy" (Evans-Pritchard 1974 [1940]:262). The distinction between sets and groups has the virtue of clarifying Evans-Pritchard's own distinction between tribes and their members, but it is only useful on condition that the (comparatively stable) alignments of the sets not be identified, any more than the (comparatively unstable) alignments of groups, with the structure itself.

"By far the most serious clash I witnessed (1978) "between Hāshid and Bakīl" involved about two thousand men on each side, dug in and facing each other on a common border. This was spoken of as one of the largest turnouts since the end of the civil war in 1970, but represents less than 10 percent of the adult male population.

'in what follows, only an outline is given of the means by which alliances are formed or repudiated. A fuller account will appear in a book-length treatment of the ethnography, which is now in progress.

${ }^{13} \mathrm{An}$ analysis of social structure by way of hypothetical questions about solidarity in cases of vengeance, which one still finds fieldworkers attempting, therefore works very poorly in this case. Tribesmen are well 
aware of the variability, and the more alert of them are quite clear that they can develop or constrain the spread of involvement. The different "rules" one elicits for the division of blood-money indicate where the ambiguities lie.

${ }^{14}$ These differences are typically spoken of in terms of the importance of the arbitrators whom the case involves, and the penalties due for breaking the truce that these arbitrators impose. The importance of the arbitrators, usually shaykhs, and of the dispute are two sides of the same coin. For a brief sketch of arbitration see Dresch 1984a:39-42.

${ }^{15}$ Immediately after the famous block diagram of $A, B, X, Y, X_{1}$ and $X_{2}$ (Evans-Pritchard 1974 [1940]:144), comes a detailed account of some actual disputes among the Nuer that do not follow the simple pattern that the diagram suggests. Had Evans-Pritchard been concerned with a causal model, as so many subsequent writers assume he was, he would surely have felt obliged to account for this oddity. He seems to have been concerned with how events are to be characterized, not predicted.

${ }^{16}$ Let me stress that logical precedence is not the same as temporal order. In fact, in a system of this kind, almost any political event is going to be taken as exemplifying an existing relation, hence (among other things) the very common appearance of disputes as indefinitely old. The exception will be discussed below ("Problems of change").

${ }^{17}$ It is worth stressing this point clearly. "The tribesman regards himself as the possessor of a quality called sharaf or honour, but the most important constituent of that honour seems to be the tradition of bearing arms and being capable of defending oneself and one's dependents" - those "lacking" this quality are by definition not tribesmen (Serjeant 1977:227).

${ }^{18}$ It is symptomatic that Rosen $(1979: 27,106, n .6)$ sees Meeker's paper as arguing for a "conceptual order ... almost wholly divorced from the social order." One of the merits of Meeker's paper (1976) is that, among the grand themes that perhaps irritate some readers, it deals with that most pedestrian of anthropology's topics-marriage ties and kinship. How "relational" can one get?

${ }^{19} \mathrm{Again}$ I must apologize to the reader and postpone a detailed treatment to the book-length account. However, changes of alignment by "brotherhood" are a well-established feature of Yemeni tribalism, mentioned as early as the-10th century A.D. (see, for example, Hamdani 1948:28, 56, and passim). A very famous case at the turn of the present century involved the village of al-Matrad, on the border of "lyāl Surayh and Banī Șuraym.

${ }^{20}$ The parallel, of course, is with Lévi-Strauss's "matrilateral operator" (Lévi-Strauss 1969:xxxiii). The interesting point, and the one over which Lévi-Strauss parted company with Needham (Lévi-Strauss 1969:xxxii, xxxv), is that the same structural principle that shows up in the observer's (statistical) model also shows up in the local (mechanical) model of society and in many of that society's partial representations. It is the local model, not ours, that provides the grounds for action.

${ }^{21}$ One could take a stand here and insist that there are no negative instances that "disprove" the notion of segmentation, only instances that illustrate other notions. But in practice, instances that run counter to the "rules" (as deployed in the particular case) are registered as doing so and their significance thus derives quite directly from the same categories as does that of instances that conform to the rules.

${ }^{22}$ Because of the longevity of particular tribal categories, one can use the image of a "framework" for many purposes in the Yemeni case in a way one cannot in the Moroccan. For many other purposes, as we have seen, it obscures the issues at stake.

\section{references cited}

Barnes, John

1962 African Models in the New Guinea Highlands. Man 62:5-9.

Bohannan, Laura

1958 Political Aspects of Tiv Social Organization. In Tribes Without Rulers. J. Middleton and D. Tait, eds. pp. 33-66. London: Routledge \& Kegan Paul.

Bourdieu, Pierre

1977 Outline of a Theory of Practice. R. Nice, transi. New York: Cambridge University Press.

Combs-Schilling, Elaine

1982 The Segmentary Model Versus Dyadic Ties: The False Dichotomy. Mera Forum 5(3):15-18.

Crone, Patricia

1980 Slaves on Horses: The Evolution of the Islamic Polity. Cambridge, England: Cambridge University Press.

Dresch, Paul

1981 The Several Peaces of Yemeni Tribes. Journal of the Anthropological Society of Oxford 12:7386.

1984a The Position of Shaykhs Among the Northern Tribes of Yemen. Man 19:31-49.

1984b Tribal Relations and Political History in Upper Yemen. In Contemporary Yemen: Politics and Historical Background. B. R. Pridham, ed. pp. 154-174. London: Croom Helm.

Dumont, Louis

1970 Homo Hierarchicus: An Essay on the Caste System. M. Sainsbury, transl. Chicago: University of Chicago Press. 
Dunn, Ross

1973 Berber Imperialism: The Ait Atta Expansion in Southeast Morocco. In Arabs and Berbers. E. Gellner and M. Micaud, eds. pp. 85-107. London: Duckworth.

Eickelman, Dale F.

1976 Moroccan Islam: Tradition and Society in a Pilgrimage Center. Austin: University of Texas.

1981 The Middle East: An Anthropological Approach. Englewood Cliffs, NI: Prentice-Hall.

1984 New Directions in Interpreting North African Society. In Connaissances du Maghreb: Sciences Sociales et Colonisation. J. C. Vatin, ed. pp. 279-289. Centre de Recherches et d'Etudes sur les Societes Mediterranean. Paris: Centre National de la Recherche Scientifique.

Evans-Pritchard, E. E.

1974[1940] The Nuer: A Description of the Modes of Livelihood and Political institutions of a Nilotic People. Oxford, England: Oxford University Press.

Gellner, Ernest

1969 Saints of the Atlas. Chicago: University of Chicago Press.

Gilsenan, Michael

1982 Recognizing Islam. London: Croom Helm.

Hamdānī, alHasan b. Ahmad

1948 Al-liklīl min akhbār al-yaman wa-insān himyar [The diadem of information about Yemen and the people of Himyar]. Muhibb al-Din al-Khatīib, ed. Cairo: Al-Matbacat al-Salafiyyah.

Holy, Ladislav

1979 Segmentary Lineage Systems Reconsidered. Queen's University Papers in Social Anthropology 4. Belfast: Queen's University.

Lancaster, William

1981 The Rwala Bedouin Today. London and New York: Cambridge University Press.

Lévi-Strauss, Claude

1969 The Elementary Structures of Kinship. J. H. Bell, J. R. von Sturmer, and R. Needham, transl. Boston: Beacon Press.

Meeker, Michael

1976 Meaning and Society in the Near East: Examples from the Black Sea Turks and the Levantine Arabs. International Journal of Middle East Studies 7, Part I:243-270; Part II: 383-422.

Meggitt, Mervyn I.

1965 The Lineage System of the Mae Enga of New Guinea. New York: Barnes and Noble.

Middleton, J., and D. Tait

1958 Tribes Without Rulers: Studies in African Segmentary Systems. London: Routledge \& Kegan Paul.

Peters, Emrys

1967 Some Structural Aspects of the Feud Among the Camel-herding Bedouin of Cyrenaica. Africa $27: 261-282$.

Pocock, D. F.

1961 Social Anthropology. London: Sheed and Ward.

Radcliffe-Brown, A. R.

1965 Structure and Function in Primitive Society. New York: Free Press.

Rosen, $L$.

1979 Social Identity and Points of Attachment: Approaches to Social Organization. In Meaning and Order in Moroccan Society. C. Geertz, H. Geertz, and L. Rosen, eds. pp. 19-111. London: Cambridge University Press.

Rossi, Ettore

1939 L'Arabo Parlato a San'a'. Rome: Instituto per l'Oriente.

Sahlins, $M$.

1961 The Segmentary Lineage: An Organization of Predatory Expansion. American Anthropologist 63:322-345.

Salzman, Philip C

1978 Does Complementary Opposition Exist? American Anthropologist 80:53-70.

1979 Tribal Organization and Subsistence: A Response to Emmanuel Marx. American Anthropologist $81: 121-123$.

Serjeant, R. B.

1977 South Arabia. In Commoners, Climbers and Notables. C. Van Nieuwenhuijza, ed. pp. 226-247. Leiden, Holland: Brill.

Submitted 1 July 1985

Revised version submitted 23 November 1985

Accepted 1 December 1985

Final revisions received 8 January 1986 